\title{
3 \\ Myths and Science about the Chemistry and Fertility of Soils in the Tropics
}

Pedro A. Sanchez

North Carolina State University

Raleigh, Norrh Carolina

Terry J. Logan

Ohio State Uriversity

Columbus, Ohio

In many scientific and popular publications, soils of the tropics are considered to be universally acid, infertile, and often incapable of sustained agriculFriedman, 1977; (Gourou, 1966; McNeil, 1964; Goodland \& Irwin, 1975 literature shows that universal Reiss et al., 1980; Jordan, 1985). The soil science literature shows that universal tropical soil infertility is a myth devoid of scienrent global issucs such as generated major misconceptions relevant to curbiodiversity, and climate rural poverty, land degradation, deforestation, The historical devel

lyzed by Richter and Babbar (199i) wisconception has been recently anations in the tropics in the (1) initial exploraprevalence of broad soil genesis the century (Buchanan, 1807), through the tury (Sibirtzev, 1914. Junnesis theories during the first half of the 20th cenquantitative data about the gi:nerated largely during the second half of this cement of snils in the tropics, cite telli.,z examples of how major ecolo this cent IIry. Richter and Babbar about soils, and conclude that the myth is a conts still use obsolete concepts munications gap between soil scientists and consequence of a major comNewer books, prodicts of multidisciplinary offor environmental scientists. aside (Leith \& Werger, 1989. Colstinary efforts, put this misconception The myth about universal coleman et al., 1989).

teracter by two kinds of evidence. Firstertility in the tropics is readily coun(Sanchez \& Buol, 1975; Moormann \& Van vast diversity of soils in the tropics 1978) which is now syst Moormann \& Van Wambeke, 1978; Drosdoff et al., Survey Staff, 1975), a world soil map (FAO quantitative soil taxonomy (Soil Copyighi S. Segoe Rd. 1992 Soil Science Society of America and American Sociely of Agronomy, 677 cial Publication no. 29 , 53711, USA. Myths and Science of Soils of the Tropics. SSSA 
increasingly accurate databases and geographic information systems (Sombrock, -986). Second, the existence of successful, sustained soil management systems in many ecosystems of the tropics (Coulter, 1972; Pushparajah \& Amin, 1977; DeDatta, 1981; Sanchez $\epsilon:$ al., 1987) pius the overwhelming evidence of sustained increases in per-capita food production in tropical Asia and Latin America (Swaminathan, 1982; FAO, 1986). Such successes, however, are concentrated on those soils of the tropics with superior chemistry and fertility and are certainly nct sufficient to overcome world fosd needs or land resource deterioration in marginal areas. Nevertheless, they are successes of such magnitude that food production has cutpaced population growth in two of the three tropical regions of the world.

We discuss the overall misconception about universal tropical soil infertility into three specific areas: soil fertility levels, clay mineralogy, and soil organic matter contents.

\section{SOIL FERTILITY PARAMETERS}

Soils are as diverse in tropical regions as they are in temperate regions. All 11 soil orders are found in both regions but their distribution varies (Table 3-1). Acid, low fertiiity soils meeting the stereotypic concept of "tropical soils" are mainly classified as Oxisols and Uitisols. Due to recent global glaciation, these soils cover only $7 \%$ of the temperate region but $43 \%$ of the tropics. Consequently, the majority of soils in the tropics (57\%) does not fit the stereotype. Generally fertile soils, classified as Alfisols, Mollisols, Verisols, and Andisols, cover a similar proportion of the temperate region (27\%) and of the tropics $(24 \%)$. Further generalizations at the order level are difficult; it is more relevant to examine specific soil-fertility parameters. It is also more relevant to subdivide the tropics into major agroecological zones.

In this chapter five of these zones are discussed: (i) humid tropics, (ii) semiarid tropics, (iii) acid savannas, (iv) tropical steeplands, and (v) tropical Table 3-1. Approximate distribution of soil orders in the temperate and tropical regions
of the world.

\begin{tabular}{lcccr} 
& \multicolumn{2}{c}{ Tropics $\dagger$} & \multicolumn{2}{c}{ Temperate region } \\
\hline Soil associations dominated by: & Million ha & $\%$ & Million ha & $\%$ \\
Oxisols & 833 & 23 & 7 &. \\
Ultisols & 749 & 20 & 598 & 7 \\
Alfisols & 559 & 15 & 1231 & 13 \\
Mollisols & 74 & 2 & 1026 & 11 \\
Entisols & 574 & 16 & 2156 & 24 \\
Inceptisols & 532 & 14 & 1015 & 11 \\
Vertisols & 163 & 5 & 148 & 2 \\
Aridisols & 87 & 2 & 2189 & 24 \\
Andisols & 43 & 1 & 101 & 1 \\
Histosols & 36 & 1 & 204 & 2 \\
Spodosols & 20 & 1 & 458 & 5 \\
\hline ILaiitudes below $231 / 2^{\circ}$ & & & &
\end{tabular}

$\dagger$ laiitudes below $23 \frac{1}{2}$.

$\ddagger$ Latitudes above $231 / 2 \circ$ wetlands. The humid tropics have high and constant temperatures and a dry season of $<90 \mathrm{~d}$. The humid tropics are, therefore, defined as areas dominated by udic soil moisture regimes or isohyperthermic and isothermic soil temperature regimes. Their native vegetation is tropical and isothermic soil decidus deciduous forest. Deforestation is the main iand degradation process involved. 9 mo duration tropics are characterized by a protracted dry season of 6 to isohyperthermic soil ten strong ustic soil moisture regime and isothermic or savanna types (Sahelian and Sudanianes. Their native vegetation are the drier as in the Brazilian Sertan and Sudanian in Wrst Africa, or thorny vegetation as in the Brazilian Sertåo). The acid savannas are seasonal tropics defined (o 6-mo duration, acid soils, and native savanna vegetation. The tropical steeplands are simply defined as those regions domithe wetlandses $>30 \%$, mainily in the mountain regions of the tropics and in the tropical steaplands are aquic soil moisture : egimes. Major limitations in the tropical stesplands are often physical (shallow rooting depth with low Erosion of Erosion of tropical steeplands may increase the base content of those soils

Grosic parent materials.

Gross estimates of the extensiveness and importance of the main soil fertility constraints are shown in Table 3-2, based on conversion of the FAO 1975. Sanch clussification system (Buol et al., 1975; Sanchez et al., 1982). Examination of that table destroys the myth of universal tropical soil infertility, and divides the problem into specific soil
fertility constraints.

\section{Low Nutrient Peserves}

About $36 \%$ of the tropics ( 1.7 billion ha) is dominated by soils with low nutrient reserves, definec as having $<10 \%$ weatherable minerals in the sand-and-si!t fraction. This constraint identifies highiy weathered soils with limited capacity to supply $\mathrm{P}, \mathrm{K}, \mathrm{C}, \mathrm{Mg}$, and $\mathrm{S}$. Soils with low nutrient reserves but are locally imporant in tropics $(66 \%)$ and in the acid savannas $(55 \%)$ thirds of soils in the tropics in the Sahel. It is relevant to note that about twothirds of soils in the tropics $(64 \%)$ do not suffer from low nutrient reserves.

\section{Aluminum Toxicity}

About one-third of the tropics ( 1.5 billion ha) has sufficiently strong soil acidity fer soluble $\mathrm{Al}$ to be toxic for most crop species. This constraint is defined as having more than $60 \% \mathrm{Al}$ saturation in the top $50 \mathrm{~cm}$ of soil. Aluminum toxicity is most prevalent in the luumid tropics and acid of soil. but occurs in large areas of the tropical steeplands. This constraint is found mainly in soils classified as Oxisols, Ultisols, and Dystropepts, and is highly to note that Al toxicity does not occur in two-thirds of the tropics. 


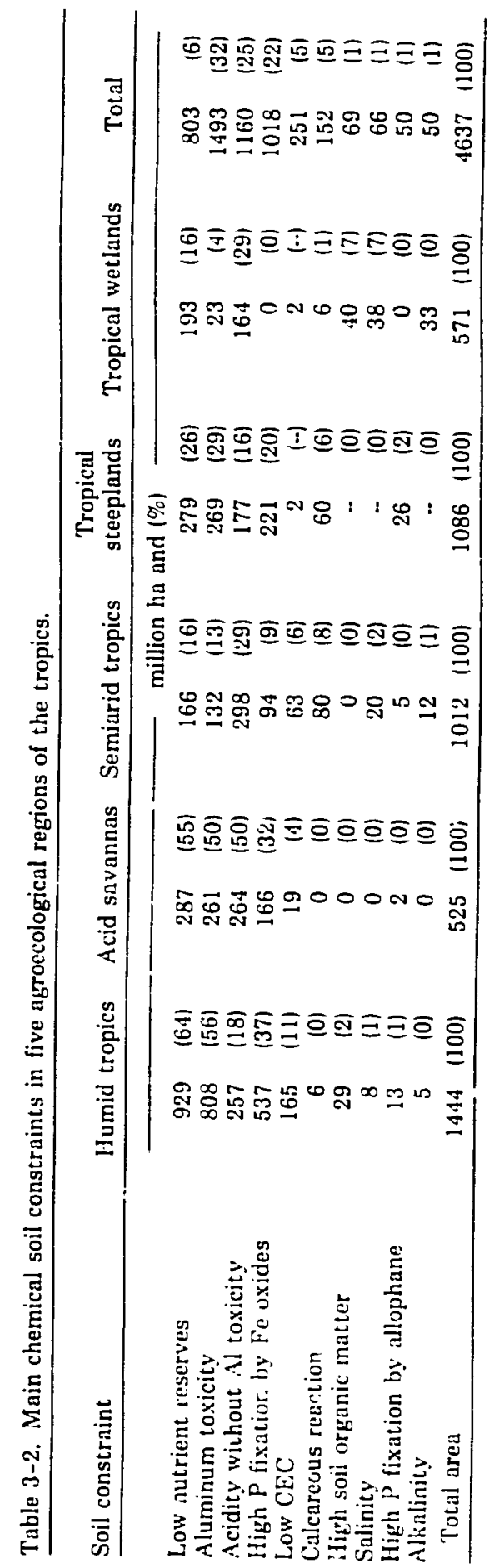

\section{Moderate Soil Acidity}

Acid soils with surface $\mathrm{f}^{\prime}$ ' lower than 5.5 but not Al toxicity' occupy one-four: h of the tropics (1.1 billion ha) and are important in all agroecoacid-susceptible hough correcting soil acidity by liming might be limited to (Medicago sativa $\mathrm{L}$ ), such as cotton (Gossypium hirsutum L.) and alfalfa higher fertilizer requirith somewhat higher fertili?er requirements for these soils than those with higher $\mathrm{pH}$ values.

\section{High Phosphorus Fixation}

Clayey soils with iron oxide/ciay ratios $>0.2$ fix large quantities of added $P$ (Buol et al., 1975). This constraint, considered very typical of the tropics, in the humid tropics and acid 1 billion ha) of the region. It is more extensive Successful management acid savannas but is also important in the steeplands. been developed for the acid savannas in $\mathrm{P}$ fixation is related to high savannas in Brazil (Goedert, 1985). Since high loamy Oxisols do to high clay coritent, most sandy and loamy Ultisols and phorus fixation is also imporant in Andis $P$ (Lopes \& Cox, 1979). Phoslophane. This constraint is int in Andisols because of the presence of alwhere volcanic soils are found Managt in the steeplands and humid tropics designed to overcome found. Management practices are dirferent from those designed to overcome P fixation by sesquicxides.

\section{Low Cation Exchange Capacity}

Soils with $<4 \mathrm{cmol}_{\mathrm{c}} \mathrm{kg}^{-1}$ of effective cation exchange capacity (ECEC) occupy only 250 million ha or about $5 \%$ of the tropics. Such low ECEC values in the topsoil indicate limited ability to retain nutrient cation against leachalleging that tropical soils are incapatle of the universal soil infertility myth, $4 \mathrm{cmol}_{\mathrm{c}} \mathrm{kg}^{-1}$ of ECEC is !ncapable of retaining nutrients. The limit of $10 \mathrm{cmol}_{\mathrm{c}} \mathrm{kg}^{-1}$ of CEC is equivalent to $7 \mathrm{cmol}_{\mathrm{c}} \mathrm{kg}^{-1}$ of CEC at $\mathrm{pH} 7$ or (Buol et al., 1975). The at $\mathrm{pH} 8.2$, the other two commonly used methods tisols, Spodosols, very main soils exhibiting such low CEC are sandy Enof Oxisols. The data in Table 3-2 irsols, and Ultisols and acric great groups $(95 \%)$ does not suffer from this proble that the vast majority of the tropics than-expected soil organic mater coblem. This is partially due to the highervide a source of CEC. Cation-leaching problems the tropics, which prothey do in the temperate

In addition, manv subsoils of coxisols, significant anion exchangsils of Uxisols, Ultisols, and Andisols exhibit nutrient anions such as nitrates and which decreases leaching losses of property is also stlch as nitrates and sulfates (Kinjo \& Pratt, 1971). This in the temperate region. 


\section{Calcareous Reaction}

Soils with $\mathrm{pH}$ values above 7.3 and with free $\mathrm{CaCO}_{3}$ within the top 50 $\mathrm{cm}$ are often deficient in micronutricats, particularly Fe and $\mathrm{Zn}$ (Lopes, 1980). Some also show imbaiances between $\mathrm{Ca}, \mathrm{Mg}$, and $\mathrm{K}$. Although calcareous soils occupy $<5 \%$ of the tropics, their relative importance is not reflected in that figure, because they are usually in: ansively utilized, such as in Central Luzon. Philippines (Neue \& Mamaril, 1;88) and in the Cauca Valley of Colombia (Blasco \& Soto, 1978; Ramirez, 1979).

\section{High Soil Organic Matter}

Organic matter ievels $>30 \%$ define organic soils (Histosols) and, unlike widespread beliefs, pose major soil fertility constraints. Organic soils are notoriously deficient in $\mathrm{Cu}$, provide poor support for roots, and many exhibit $\mathrm{H}$ toxicity. There are approximately 69 million ha of Histosols and other closely related soils in the tropics, of which half are in southeast Asia (Driessen, 1978). A!though organic matter is considered a desirable soil property, too much soil organiz matter is definitely not (Sanchez \& Miller,
1986).

\section{Salinity and Alkalinity}

Sixty-six million ha of the tropics have serious salinity problems, with electrical conductivit; $>4$ and $5 \mathrm{dS} \mathrm{m} \cdot{ }^{\prime}$ in the top $1 \mathrm{~m}$. Fifty million ha are alkaline with more than $15 \% \mathrm{Na}$ saturation within the top $50 \mathrm{~cm}$. Although each ui these constrainis occupy $<1 \%$ of the tropics, they are loThey occur primarily in the humid tropics, semiarid tropics, and wetlands.
Thend important (Aguilera, 1979; Ponnamperuma \& Bandyopadhya,

\section{Geographical Distribution}

The extent of these soil-fertility constraints in the develcping world is shown in Table 3-3 for tropical and subtropical areass of Latin America, Afri$\mathrm{ca}$, and Asia. Their relative importance varies with continental constraints. For example, problems related to soil acidity are mote extensive in Latin America than in Africa or Asia. Examination of Tables 3-2 and 3-3 give little support to the myth of universal tropical soil infertility.

\section{CLAY MINFRALOGY}

A second major myth about the chemistry and fertility of tropical soils is that they are dominated by kaolinite, iron oxides, and other highly weat hered clay minerals. Such minerals are now classified as variable charge clays, where CEC increases with soil $\mathrm{pH}$, as opposed to permanent charge minerals such as smectites, illite, vermiculite, and chlorites (Theng, 1980). \begin{tabular}{l} 
(includes tropical and subtropiral regions). \\
\hline
\end{tabular}

\begin{tabular}{|c|c|c|c|c|c|c|c|c|}
\hline \multirow[t]{2}{*}{ Soil constraint } & \multicolumn{2}{|c|}{$\begin{array}{c}\text { Latin } \\
\text { America }\end{array}$} & \multicolumn{2}{|c|}{ Africa } & \multicolumn{2}{|c|}{$\begin{array}{l}\text { South and } \\
\text { southeast } \\
\text { Asia }\end{array}$} & \multicolumn{2}{|c|}{$\begin{array}{l}\text { Developing } \\
\text { world }\end{array}$} \\
\hline & & & ? & illion $t$ & $a$ and & $(\%)-$ & & \\
\hline Low nutrient reserves & 941 & (43) & 615 & $(20)$ & 261 & $(161$ & 1817 & $(2 \pi)$ \\
\hline $\begin{array}{l}\text { Aluminum toxicity } \\
\text { High P fixation }\end{array}$ & 821 & (38) & 479 & (16) & 236 & (15) & 1527 & (23) \\
\hline $\begin{array}{l}\text { High P fixation by Fe oxides } \\
\text { Acidity without }\end{array}$ & 615 & (28) & 205 & (7) & 192 & (12) & 1012 & $115 \mathrm{j}$ \\
\hline $\begin{array}{l}\text { Acidity without Al toxicity } \\
\text { Calcareous reaction }\end{array}$ & 313 & (i4) & 471 & (16) & 320 & (20) & 1104 & (16) \\
\hline $\begin{array}{l}\text { Calcareous reaction } \\
\text { Low CEC }\end{array}$ & 96 & (4) & 332 & (11) & 360 & (23) & 788 & (12) \\
\hline $\begin{array}{l}\text { Low CEC } \\
\text { Salinity }\end{array}$ & 118 & (5) & 397 & (13) & 67 & (4) & 582 & (9) \\
\hline Salinity & 62 & (3) & 75 & (3) & 97 & (6) & 234 & (3) \\
\hline Alkalinity & 35 & (2) & 18 & $(-)$ & 7 & $(-1)$ & 60 & (1) \\
\hline High P fixation by allophane & 44 & $10 i$ & 5 & $(-)$ & 7 & $(-1)$ & 56 & (1) \\
\hline High soil organic matter & 9 & $(--)$ & 12 & $(-1)$ & 23 & (1) & 44 & $(\cdot-)$ \\
\hline Total area & 2172 & $(100)$ & 3011 & $(100)$ & 1575 & (100) & 6758 & $(100)$ \\
\hline
\end{tabular}

Uehara and Gillman (1981) calculated the distribution of soils with variat 2.2 mixed, or permanent charge. Given the fact that mixtures of clay minerals is the norm rather than the exception in soils anywhere, Gillman and Uehara defined variable-charge soils as those where more than $60 \%$ of the ECEC where $<40 \%$, mixed as those between 40 and $50 \%$, and pcrmanent as those of soil organic the charge is variable Also given the fact that the ECEC variable charge. ii the tropics have variabla, shown in Table 3-4, indicate that $60 \%$ of soils In contrast $10 \%$ variable charge, while only $10 \%$ have permanent charge. $45 \%$ has permaner: the temperate region soils have variable charge while charge is the dominant fearge. There is no question, therefore, that variable a universal chaminant feature of soils of the tropics, but it is certainly not a universal characteristic of the tropics. The 820 million ha of soils with variHistosols, in the temperate region are found in high latitude Spodosols and Histosols, but also exist in large Ultisol areas such as southeastern USA and Northwest, and New Zealand. Table $3-1$. Extent of soils classified as variable. mixed, or permanent charge. Source:
Uehara and Gillman (1981).

\begin{tabular}{lccccccc}
\hline & \multicolumn{2}{c}{ Tropics } & \multicolumn{3}{c}{ Temperate } & \multicolumn{2}{c}{ World } \\
\hline & billion ha & $\sigma$ & billion ha & $\sigma_{0}$ & billion ha & $\%$ \\
Variable $\dagger$ & 3.00 & 60 & 0.82 & 10 & 3.82 & 29 \\
Mixed chargef & 1.50 & 30 & 3.68 & 45 & 5.18 & 39 \\
Permanent charge $\delta$ & 0.50 & 10 & 3.68 & 45 & 4.18 & 32 \\
\hline
\end{tabular}

$\$ 40-60 \%$ of ECEC is variable.

$\S<40 \%$ of CEC is varisible. 


\section{SOIL ORGANIC MATTER CONTENTS}

It is commonly believed that soils of the tropics have lower organic matter (SOM) contents than soils of the temperate region (McNeil, 1964; Gourou, 1966; Bartholomew, 1972; Jordan, 1985). The red color of many soils in the tropics, high temperatures, and high rainfall are among the reasons cited in support of this generalization. This assumption, however, happens to be wrong. There are no major differences in SOM contents betweet the two regions (Sanchez \& Buol, 1975; Latnwell \& Bouldin, 1981; Sanchez \& Miller, $1065)$. Interest in the world $C$ cycle has resulted in many recent estimates of soil $\mathrm{C}$ reservis in the humid tropics to answer the question of whether tropical forests are a source or sink of $\mathrm{C}$ for the world. Empirical estimates of the soil organic $C$ reserves in the tropics, such as those developed by Schlesinger (1979) and Brow'n and Lugo (1980), vary widely. Reserves are calculated by multiplying organic $\mathrm{C}$ data from a few soil profiles by the land area represented by such soils or by the land area of the ecological region in which they are found. Schlesinger and Brcwn and Lugo recognized these weaknesses and urged some precise estimates. The soil science literature, however, has many reports indicating that soils of the tropics are not generally low in organic matter. Kellogg (1950) made this point very clear more than $30 \mathrm{yr}$ ago. Studies of several hundred topsoil samples from Hawaii (Dean, 1930). Puerto Rico (Smith et al., 1951), and Eäst Africa (Birch \& Friend, 1956) showed average topsoil vaiues on the order of $2 \% \mathrm{C}$, a figure that compares favorably with temperate region coltents.

Studies involving large numbers of pedons (Post et al., 1982; Zinke et al., 1984; Sanchez et al., 1982) now confirm the prevalent view that soil organic matter contents vary equally ir temperate and tropical regions (Duxbury et al., 1989). For example, data .rom 61 randomly chosen profiles from the tropics and 45 from temperate regions and classified as Oxisols, Mollisols, Alfisols, and Ultisols, showed no significant differences in total $\mathrm{C}$ and $\mathrm{C} / \mathrm{N}$ ratios between soils from tropical or temperate regions at depth intervals up to $100 \mathrm{~cm}$ (Table 3-5). Total $\mathrm{N}$ sontents, however, were significantly higher in the tropical samples while the coefficients of variability were similar. No significant differences in SOM contents were observed between Alfisols from the tropics vs. Alfisols of the temperate region, Ultisols from the tropics vs. Ultisols of the temperate reginz and Mollisols of the tropics vs. Mollisols of the temperate region (Sanchez et al., 1982). Furthermore, no significant differences in organic matter contents were found between the classic black Mollisols or Chernozems of the temperate region and the red, highly weathered Oxisols of the tropics (Table 3-6).

A recent analysis of well-classified pedons from the National Soil Survey Laboratory database with 282 pedons from the tropics (having isotemperature regimes) and 486 pedons from the temperate regions (non isotemperature regimes) suggest that soils from the tropics may have significantly higher SOM contents to $30-\mathrm{cm}$ depth than soils from temperate regions (Buol et al., 1990). The data shown in Fig. 3-1 is arranged according to the mean annual temperature of the four main soil temperature regimes in soil
Table 3-5. Mean organic matter contents in 61 soils from the tropics vs. 45 soils from the temperate region. Source: Sanchez et al. (1982).

\begin{tabular}{llccccc}
\hline Parameters & $\begin{array}{c}\text { Depth. } \\
\text { cm }\end{array}$ & $\begin{array}{c}\text { Tropical } \\
\text { soils }\end{array}$ & $\begin{array}{c}\text { Temperate } \\
\text { soils }\end{array}$ & Significance & Tropics & Temperate \\
\hline$\% \mathrm{C}$ & $0-15$ & 1.58 & 1.64 & NS & 53 & 64 \\
& $0-50$ & 1.10 & 1.03 & NS & 57 & 69 \\
$\% \mathrm{~N}$ & $0-100$ & 0.69 & 0.62 & NS & 59 & 75 \\
& $0-15$ & 0.153 & 0.123 & $*$ & 62 & 57 \\
& $0-50$ & 0.109 & 0.090 & NS & 57 & 57 \\
C/N ratio & $0-100$ & 0.078 & 0.060 & $* *$ & 54 & 52 \\
& $0-15$ & 13.7 & 13.6 & NS & 79 & 35 \\
& $0-50$ & 11.3 & 11.3 & NS & 46 & 32 \\
& $0-100$ & 9.6 & 10.0 & NS & 46 & 35 \\
\hline
\end{tabular}

*.** Significant at the 0.05 and 0.01 probability levels, respectively.

Table 3-6. Mean total $\mathrm{C}$ and $\mathrm{N}$ reserves of soil orders by geographical regions. Source: Sanchez et al. (1982).

\begin{tabular}{|c|c|c|c|c|c|c|}
\hline \multirow[b]{2}{*}{ Region } & \multirow[b]{2}{*}{ Soil order } & \multirow{2}{*}{$\begin{array}{c}\text { No. cf } \\
\text { profiies }\end{array}$} & \multicolumn{2}{|c|}{ Total C } & \multicolumn{2}{|c|}{ Total N } \\
\hline & & & $0-15 \mathrm{~cm}$ & $0-100 \mathrm{~cm}$ & $0-15 \mathrm{~cm}$ & $0-100 \mathrm{~cm}$ \\
\hline Tropics & $\begin{array}{l}\text { Oxisols } \\
\text { Alfisols } \\
\text { Ultisols }\end{array}$ & $\begin{array}{l}19 \\
13 \\
18\end{array}$ & $\begin{array}{l}3.8 a^{*} \\
2.9 a^{2} \\
2.1 b\end{array}$ & $\begin{array}{r}11.3 \mathrm{a} \\
6.4 \mathrm{~b} \\
6.4 \mathrm{~b}\end{array}$ & $\begin{array}{l}0.32 \mathrm{a} \\
C .29 \mathrm{a} \\
0.1 \delta \mathrm{c}\end{array}$ & $\begin{array}{l}1.13 a \\
0.85 b \\
0.69 b\end{array}$ \\
\hline Temperate & $\begin{array}{l}\text { Moll sols } \\
\text { Alfisols } \\
\text { Ultisols } \\
\end{array}$ & $\begin{array}{r}21 \\
16 \\
8 \\
\end{array}$ & $\begin{array}{l}3.3 \mathrm{a} \\
2.8 \mathrm{ab} \\
2.4 \mathrm{~b} \\
\end{array}$ & $\begin{array}{r}10.1 \mathrm{a} \\
5.8 \mathrm{~b} \\
4.2 \mathrm{~b} \\
\end{array}$ & $\begin{array}{l}0.27 \mathrm{a} \\
0.20 \mathrm{bc} \\
0.15 \mathrm{c} \\
\end{array}$ & $\begin{array}{l}0.95 a \\
0.56 c \\
0.44 c\end{array}$ \\
\hline
\end{tabular}
* Numbers followed by the same lower case letter are not significantly different at the
$P<0.05$ level.

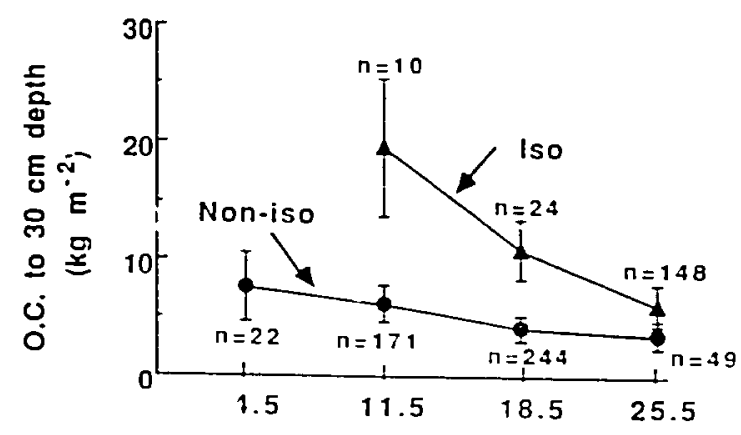

Family Mean Temperature $\left({ }^{\circ} \mathrm{C}\right)$

Fig. 3-1. Soil organic $C$ contents as a function of soil temperature regime in iso (tropical) vs. non-iso (temperate) regions. Source: Buo! et al. (1990). 
taxonomy: frig: $d\left(4.5^{\circ} \mathrm{C}\right)$, mesic $\left(11.5^{\circ} \mathrm{C}\right)$, thermic $\left(18.5^{\circ} \mathrm{C}\right)$, and hyperther $\operatorname{mic}\left(25.5^{\circ} \mathrm{C}\right)$. Although there is a general decrease in SOM content with in creasing temperature, those soils with little seasonal temperature variation indicative of the tropics (isomesic, isothermic, or isohyperthermic regimes) show higher SCM contents than those with strong seasonal temperature variation in mesic, thermic, and hyperthermic regimes.

Soil is a temporary repository for organic C (Buol et al., 1990). Soil organic matter content, therefore, is a function of additior: and decomposition rates. Calculations from Greenland and Nye (1959) suggest that generally higher SOM decomposition rates found in the humid tropics caused by high teinperatures and ample moisture are balanced by higher litter input, both factors being about five times higher in soils from tropical forests than from temperate forests (Sanchez, 1976). Many processes operating at sitespecific rates affect actual input and decomposition rates and provide a wide range of equilibrium SOM contents (Anderson \& Swift, 1984). It is safe to assume, therefore, that the range in SOM contents in the tropics is as variable as in the temperate region.

Unfortunately, there is no direct correlation between SOM contents and soil fertility as measured by crop productivity, other factors being constant (Sanchez \& Miller, 1986). Mollisols shown in Table 3-6 supported many crops of corn (Zea mays L.) without fertilization for years in midwestern USA, Europe, and Argentina (Stevenson, 1984). But many Oxisols with similar SOM contents will definitely not be able to keep one corn plant alive without fertilizer additions (Lopes, 1983). This discrepancy is rclated to deficiencies of nutrients other than $\mathrm{N}$, and Al toxicity in Oxisols.

\section{CONCLUSIONS}

Soils of the trojics are variable in their chemistry and fertility, ranging from the most fertile to the most infertile in the world. Although there is a larger proportion of acid soils in the tropics, they are :sot even in the majority. The chemical processes involved are the same regardless of latitude. What is different is their management, because of different climate, crop species, and socioeconomic conditions found in the tropic..

Given the expanding databases available from the tropics on inherent soil characteristics, and on their management, it is no longer acceptable to continue the myths of the past that were understandably caused by a lack of systematic study. Site-specific management will be increasingly necessary as demands grow on soils of the tropics for food and fiber production.

\section{REFERENCES} Aguilera, F. 1979. El problema de la salinidad y el sodio en el Valle del Cauca. Suelos Ecuat.
10:98-114.

Anderson, J.M., and M.J. Swift. 1984. Decomposition in tropical rainforests. p. 287-309. In

S.L. Sutton, et al. (ed.) The tropical rainforest. Blackwell Sci. Publ. Oxford, UK.
Bartholomew. W. Y. 1972. Soil nitrogen and organic matter. p. 63-81. Soils of the humid tropio Natl. Acad. Sci., Washington, DC

Birch, H.F. and M.T. Iriknd. 1956. The organic matter and nitrogen status of East African i. $7: 156-167$

Blasco, M., and C. Soto. 1978. Estado actual de las investigaciones sobre micronutrientes en America latina. Suelos Eiat 9:160-164.

Brown. S., and A. E. Lugo. 1980. The role of tropical forests on the world carbon cycle. Centre for Wetlands, Unir. of Florida. Gainesville.

Buchanan, F, 1807. A journey from Madras through the countries of Mysore. Canara, and Nalabar. Vol. 2. W. Bulmer and Co.. Si. James; East India Co.. London.

Buol, S. W., P.A. Sanchez. R. B. Cate, and M.A. Granger. 1975. Soil fertility capability classification. p. 126-1+1. In E. Bornenisza and A. Alvarado (ed.) Soil Management in tropical America. North Carolina State Unir., Raleigh.

Btiol, S.W.. P. A Sanchez, J Mimble and S. Weed warming on soll properties and use. p. $71-82$. In B.A. Kinball ct al. (ed.) Impact of car bon dioxide irace gases, and climate change on global agricultuı ASA Spec. Publ. 53 ASA, CSSA, and SSSA. Madison, Wi.

Coleman, D C J U Oades, and $\mathrm{G}$. Uenara (ed, tropical ccosystens. Unes, and G. Uenara (ed.). IS 89 . Dỵamics of soil organic matter in tropical Press. Honolulu. Coulter. J.K. 1972. Soil management systems. p. 189-197. In Soils of the humid tropies. Natl.
Acad of Sci. Washington. DC.

Dean, A.L. 1930. Nitrogen and organie inatter in Hawaiian pineapple coils. Soil Sci. 30:439-442.

DeDatta, S.K. 1981. Pritciples and practices of rice production. John Wile and Sons. New York.

Driessen, D.M1. 1978. Peat soils. p. 763-779. In Soils and rice. Int. Rice Res. Inst.. L.os Baños, Philipnines.

Drosdoff. M., R.B. Daniels, and J.J. Nicholaides (ed.) 1978. Diversity of soils in the tropics. ASA Spec. Publ. 34. ASA. Madison. WI

Duxbury, J.M., M.S. Smith, and J.W. Doran. 1989. Soil organic matter as a source and a sink of plant nutrients. p. 33-67. In D.C Coleman et al. (ed.) Dynamics of coil organic matter in tropical ecosystems. Univ. of Hawaii Press, Honolulu.

Food and Agriculture Organization of the United Nations. 1971-19:9. Soil map of the world. 9 volumes. UNESCO. Paris.

Food and Agriculture Organization of the United Nations. 1986. Yearbook of agriculture for 1985. FAO, Rome

Friedinan. 1. 1977. The Amazon basir, another Sahel? Science 197:7

Goedert, W.J. (ed.) 1985. Solos do cerrados: Tecnologiac e manejo. Nohel, Så Paulo.

Goodland, F.J.A.. and H.S. Irwin. 1975. Amazon jungle: Green hell to Red Desert? Elsevier. Amsterdan.

Gourou, P. 1966. The tropical worki: Its social and economic conditions and its future status. thed. (Trans. W.y. S.H. Beaver and E.D. Laborde.) L.nngmans, London.

Greenland, D.J., and P.H. Nyc. 1959. Increases in carbon and nitrogen contents of tropical soils under natural fallous. J. Soil Sci 9-28 $4-299$.

Irion, G. 1978. Soil infertility in the Amazonian rainforent. Naturwissenschaften 65:515-519. Jenny, H. :94i. Factors of soil formation. MeCiraw-Hill. New York. Jordan, C.F. 1985. Nutrient cycling in tropical forest ecosystems. John Wiley and Sons, New
Yor:..

Kellogg, C.E. 1950. Tropical soils. Trans, th Int. Congr. Soil Sci 1.266-276.

Kinjo, T., and P.F. Pratt. 1971. Nitrate adcorption. Soil Sci. Soc. Am. Proc. 35:722-732.

Lathuell, D.J., and D.R. Bouldin. 1981. Soil organic matter and nitrogen behavior in cropped soils. Trop. Agric. (Trinidad) $58: 3+1-348$

Leith, H., and M.Fi.A. Werger. (ed.). 1989. Tropical rainforest ecoswtems: Biogeographical and ecological studies. Feosystems of the world $1+B$. Flsevier. Ansterdam.

Logan, T.J., and L.R. Cooperband. 1987, Soil erosion on cultivated steeplands of the humid tropics and subtropies. P. $21-38$. In D.D. Southeate and J.F. Disinger (ed.) Sustainabie resource deselopment in the Third World. Westriew Press. Boulder, $C_{0}$

Lopes. A.S. 1980. Nicronutrient in soils of the tropics as constraints to food production. 277-298. In Priorities for alleviating soil-related constraints to food production in the tropics. A.S. 1983 . Solos sob cerrado. Inst 
Lopes, A.S., and F.R. Cox. 1979. Relacáo de caracteristicas fisicas, químicas e mineralógicas

MicNeil, M. 1964. Laterite soils. Sci. Am. 211:68-73.

Moorman, F.R., and A. Van Wembeke. 1978. The soils of the lowland rainy tropical climates, their inherent limitations for food production and related climatic restraints. Int. Soc. Soil Sci. Trans. 1lih Congr. 2:292-312. Neue, H.E., and C.P. Mamaril. 1985. Zinc, sulfur and other micronutrients in wetland soils,
p. 307-320. In Wetland soils: Characterization, classification and utilization. Int. Kice. Res. Insı., Los Barios, Philippines.

Ponnamperuma. F.N.. and A.K. Bandyopadhya. 1930. Soil salinity a: a constraint on food production in the humid tropics. p. 203-2i6. In Priorities for alleviating soil-related con

Post, W..M..W.R. Emanuel. P.J. Zinke, and A.G. Stangeberger. 1982. Soil carbon pools and world life zones. Nature (London) 298:156-159.

Pushparajah, E., and L.L. Amin. 1977. Soils under Hevea in peninsular Malaysia and their management. Rubber Res. Inst. of Malaysia, Kuala Lumpur.

Ramirez, A. 1979. Evaluacion de la relacion calcio/magnesio en sielos del Valle del Cauca.
Suelos Ecuat 10:147-155

Reiss, S., L. Rother, H. Jensen, B. Came, J. Taylor, and M. Lord. 1980. Vanishing forest. Newsweek 24:117-122

Richter. D.D., and L.1. Babbar. 1991. Soil diversity in the tropics. Adv. Ecol. Res. 21:315-389. Sanchez, P.A. 1976. Properties and management of soils in the tropics. John Wiley and Sons, New York.

Sanchez, P.A., and S.W. Buol. 1975. Soils of the tropics and the world food crisis. Science 188:598-603.

Sanchez, P.A., W. Couto, and S.W. Buol. 1982. The fertility capability soil classification system: Interpretation, applicability and modification. Geoderma 27:283-309.

Sanchez, P.A. M.P. Gichuru. and L.B. Katz. 1982. Organir matter in major soils of the tropical and temperate regions. Int. Congr. Soil Sci., 12th (New Delhi) 1:99-114.

Sanchez, P.A., and R.H. Miller. 1986. Organic matter and soil fertility management in acid soils of the tropics. Int. Soc. Soil. Sci. Trans. 13th Congr. 6:609-625.

Sanchez, P.A.. E. Pushparajah, and E.R. Stoner (ed.). 1987. Management of acid tropical soils for sustainable agriculture. IBSRAM Proc. No. 2, Bangkok. Thailand.

Schlesinger, W.. II. 1979. The role of terrestrial vegetation in the global carbon cycle: Methods 1. Appraising changes. G.A. Woodwell (ed.) John Wiley and Sor.s, New York.

Sibirtzev, N.M. 1949. Soil science. (Transl. N. Kaner). Israel Prog. for Sci. Transl., and I'SDA. Jerusalem and Washington, DC.

Soil Survey Staff. 1975. Soil taxonomy: A basic system of soil classification for making and interpretung soil surveys. USDA Handb. 436. U.S. Gov. Print. Office. Washington, DC. Smith, R.M., G. Samuels, and C.F. Cernuda. 1951. Organic matter and nitrogen build-ups in some Puerto Rican soils profiles. Soil Sci. 72:409-427.

Sombroek, W.G. 1986. Establishment of an international soils and land re ources information base. SOTER Rep. 1:118-124. Int. Soils Ref. and Info. Centre. Wageningen. Netherlands.

Stevenson, F.J. 1984. Cycles of soil. john Wiley and Sons, New York.

Swaminathan, M.S. 1982. Our greatest challenge: Feeding a hingry world. p. 25-46. $\ln$ G. Bixier and L.W. Shemil: (ed.). Chemistry and world food supplies: The new frontiers. Int. Rice

Theng, B.K.G. (ed.). 1980. Soils with variable charge. New Zealand Soils Bureau. Lower Hutt, NZ.

Uehara, G., and G. Gillman. 1981. The mineralogy, chemistry and physics of tropical soils with variable charge clays. Westview Press, Boulder, CO.

Zinke, P.J., A.G. Stanganberger, W.M. Post, W.R. Emanuel, and J.S Olson. 1984. World wide organic soil carbon and nitrogen data. ORNL/TM-8875. Oak Ridge Natl lab. Oak Ridge, TNS. 